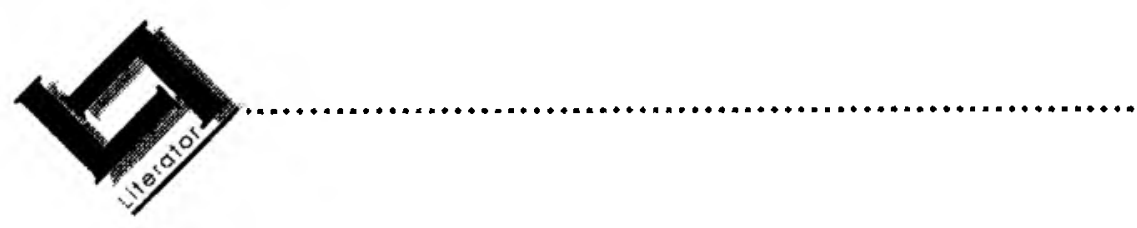

\title{
Die politiek van herinnering: spore van trauma
}

Johan Snyman

Departement Filosofie

Randse Afrikaanse Universiteit

JOHANNESBURG

E-pos: jis@lw.rau.ac.zo

Abstract

The politics of memory: Vestiges of trauma

The politics of memory is fraught with paradoxes; however, it remains an unavoidable and necessary strategy to cope with (historical) trauma. After a brief concept of historical memory has been outlined, an analysis follows of the various strategies of memory that have been employed to deal with the trauma of the British concentration camps during the Anglo-Boer War of 1899-1902. The point of the analysis centres in the moral universalisability of the politics of traumatic experience. The initial male strategy of memory (heroization) is found wanting. Emily Hobhouse's observations and interpretation of suffering are important criticisms of this initial strategy. In the final instance, it is the interpreted voice of the victim herself that makes trauma audible - by approximation.

\section{Te veel / te min onthou / vergeet}

As dit nodig is om amnestie te verleen om uit die doodloopstrate van 'n slopende politieke vete te kom, word amnesia - historiese geheueverlies - ook wet? Beteken dit dat daar nou bladsye uit die boek van die geskiedenis geskeur word wat vredesonthalwe nooit meer gelees mag word nie? Is te veel onthou 'n siekte? Wat van te veel vergeet? Hoekom wil of moet 'n samelewing vergeet? En saam met die vergeet, hoekom wil of moet 'n samelewing onthou? Hoe staan die begeerte en die verpligting om die verlede te onthou en die begeerte en die verpligting om te vergeet van die verlede met mekaar in verhouding? Hoeveel waarheid sit daar in die pleidooi vir "vergewe en vergeet"? 
Daar is verskillende strategieë om te vergeet. Diegene met slegte gewetes wil graag hê dat veral ander moet vergeet en gehelp word om te vergeet. Dan is daar ook diegene wat deur groot traumas is, wat nie graag die trauma weer wil beleef deur herinner te word nie. Is hierdie twee soorte vergeet egter dieselfde? "Wat verby is, is verby" - vir diegene met die slegte gewete genadiglik, want daarmee is die gevaar van verantwoording en afstand doen van watter voordele ook al besweer; en wat verby is, is verby vir die slagoffers, ook genadiglik, want daardeur hoef die gebeure en omstandighede van die diepste aanvegting van die betekenis van die lewe nie weer aan die groot klok gehang te word nie (vgl. Wieseltier, 1993). Maar die "sameswering van stilte" (vgl. Danieli, 1981) is nie 'n volhoubare strategie nie. Trauma, enige trauma, laat homself nie vergeet nie. Trauma is die diepgaande versteuring van en skok in die verhouding tot die self, die verhouding met ander mense en die verhouding met die wêreld in die algemeen (vgl. Herman, 1992:51-73; 115-129). Hierdie verhoudings konstitueer die subjektiwiteit van die mens wederkerig. As een van hierdie verhoudings nie bewus betekenisvol beleef (kan) word nie, voel die mens dat daar iets aan sy/haar bestaan haper. Daarom het 'n diepgaande beskadiging van een of al hierdie verhoudings ook 'n langdurige effek op die mens se lewe. Trauma is nie soos 'n kwaai verkoue wat een of ander tyd oorgaan nie. Dit laat permanente letsels. Dit kan mense permanent geestelik mank laat, tensy hulle op een of ander manier leer om met die letsel saam te leef. Die probleem is om, ten minste, sinvol met die letsel saam te leef, of, op die meeste, sinvol bo die letsel uit te leef. Anders is die opsie om óf permanent slagoffer met die gepaardgaande slagoffermentaliteit (voortdurende wantroue, selfs paranoia, negatiwiteit) te wees, of ' $n$ mens ontken die belemmering van die letsel en leef in oormatige vertroue (prestasie as kompensasie) asof daar nooit iets gebeur het nie. Dan gaan trauma ondergronds.

Daar is net soveel strategieè om te onthou. So byvoorbeeld beywer die oorwinnaars hulle vir die voortdurende herdenking van die grootse oomblik(ke) in die stryd. En veral die nakomelinge van sowel oorwinnaars as slagoffers wil dat die verlede onthou word (vgl. Pawelczynska, 1979:1-5; Tec, 1986:vii-ix) op die oog af om dieselfde rede, naamlik dat wat herdenk word, "nooit weer mag gebeur nie". Paradoksaal genoeg moet die verpligting tot herinnering werk as 'n voorbehoedmiddel: deur die voorstelling van die slegte gebeure in die (kollektiewe) herinnering moet die huidige en toekomstige historiese agente afgeskrik word van 'n daadwerklike teenwoordigmaking van die slegte in die geskiedenis. Representasie (in die herinnering) moet representasie (in die werklikheid) verhoed. Die herinnering het 'n politiek - dit is om die vermoë tot onthou te mobiliseer tot voordeel van die inrigting van die menslike wêreld. As sodanig is die herinnering ingekapsel in die spel van die vermoëns van die mens om die wêreld vir hom- of haarself bewoonbaar (of onbewoonbaar) te maak. 
Maar die historiese herinnering as voorbehoedmiddel is gelaai met verskillende ervaringsinhoude. Aan die een kant wil die oorwinnaars die trauma van die onreg onthou omdat dit sin kan kry uit die werklik geworde en behaalde oorwinning oor die onreg - die lyding was nie tevergeefs nie. Aan die ander kant wil (veral die nakomelinge van) slagoffers die trauma van onreg onthou om sin te gee aan die lewe van die (gestorwe) slagoffers - hulle lewens kan nie sommer net in die afvalblik van die geskiedenis beland nie. Herinnering by (oorlewende) slagoffers (en nakomelinge van slagoffers) is 'n strategie om die waardigheid van die verlore slagoffer te herstel, en in daardie herstel iets te beleef van ' $n$ eie herstel. Herdenking is daarom, in watter sin ook al, 'n strategie om trauma te verwerk, asook 'n ritualisering of ' $n$ institusionalisering van so ' $n$ strategie (vgl. Hobsbawm \& Ranger, 1983)1. Ritualisering van herinnering vind plaas in die veral plegtige herhaling van die aktiwiteit van onthou (die herdenkingsgeleentheid as 'n private of openbare funksie op gereelde tye). Institusionalisering vind plaas deur die instandhouding van 'n minimumkonsensus oor die grondliggende feite van 'n ingrypende en deurslaggewende historiese gebeure én die waardes wat daaraan geheg kan word (die totstandkoming van legendes, vertellings, geskiedenisse in gemeenskapsverband).

Dit behoort duidelik te wees dat hierdie strategie dialekties is, en daarom baie maklik eensydig (en daarom weer mank) kan word. (Nie dat sogenaamde gebalanseerdheid, of die afwesigheid van mankheid sonder meer gesondheid beteken nie - die aanplak van teëwigte kan ook sonder integrasie in die gang van die geskiedenis plaasvind, dooie gewigte word en dus nie sinvolle reaksie op die omstandighede wees nie.) Die vraag is nie om sydigheid te vermy nie, maar wel om te verhoed dat sydigheid vasgroei tot mankheid. Of anders gestel: die vraag is na die vermoë om sydigheid betyds te kantel om 'n sinvolle oor die weg kom met die gang van die menslike werklikheid moontlik te maak. Hierdie kanteling van sydighede is deel van die spel van die herinnering. Die oproep van die heldedaad roep ook die wandaad waarteen die heldedaad gereageer het, op. Die verlede bestaan nie net uit helde nie, maar ook uit skurke. En die eie verlede word nie net deur helde of skurke bevolk nie, net soos die hede. So is ook die motiverings van die helde en die skurke nie volkome eenduidig nie. Bedoeling en afloop staan ook nie altyd in 'n simmetriese verhouding nie. Die diepste

1 Hugh Trevor-Roper oor "The Invention of Tradition: The Highland Tradition of Scotland" (in Hobsbawm \& Ranger, 1983:15-42), is hier ter sake. Hy bevind dat 'n tradisie (wat in hennnerng gehou word) nie iets is wat vanuit in verlede na die hede (en die toekoms) oorgedra word nie, maar eerder iets is wat vanuit die hede in 'n verlede ontdek, belig, geherkonstitueer en selfs uitgevind word ter wille van die regverdiging van 'n eietydse en toekomstige prioriteit, soos byvoorbeeld 'n sosiale identiteit, historiese en politieke optrede, en dergelike meer. Deur hierdie uitvinding van die tradisie, veral in moderne samelewings, word sogenaande lesse uit die geskiedenis geleer en in min of meer duursame sosiale praktyke "verdiskonteer" as 'n reël vir gedrag. Vir verdere besonderhede oor die kwessie van inklusiwiteit en eksklusiwiteit by ritualisering en institusionalisering, kyk Snyman (1998). 
paradoks van die spel van die herinnering bly om die verlies aan sin as gevolg van trauma teen te werk met die oproep van die gebeure wat die sin tot niet gemaak het - maar nie 'n blote oproep nie. Die oproep is 'n poging om weliswaar na die tyd - die gebeure in 'n konteks te probeer begryp, al is die herkontekstualisering altyd net gedeeltelik. Herinnering is om gelyktydig te sê: soveel is begryplik, en soveel is onbegryplik. Jöm Rüsen druk dit kernagtig uit:

Ohne eine Erinnerung, mit der wir uns selbst in die Zukunft mitnehmen können, haben wir keine. Nur aus Erinnerung ist Zukunft lebensfahig und motivierendes und mobilisierendes Element unserer Gegenwart (Rüsen, 1998:231).

Sonder ' $n$ herinnering waarmee ons onsself in die toekoms saamdra, het ons geen toekoms nie. Net uit die herinnering is die toekoms lewensvatbaar en die motiverende en mobiliserende element van ons hede.

Met die herdenking van die uitbreek van die Anglo-Boereoorlog word nou baie meer herinneringe van mense wat ballinge of konsentrasiekampgevangenes was, gepubliseer. Die enigste omvangryke studie oor die lewe in die Britse konsentrasiekampe tot dusver, is dié van Otto (1954) wat 'n oorsig probeer gee van empiries agterhaalbare omstandighede, toestande en daaglikse roetines in die kampe. Otto beskryf die ellende van die kampe met behulp van statistiek, die reaksie van waarnemers, húlle klagtes, en die reaksie van die Britse regeringsopposisie. Otto se verklaring in sy voorwoord is veelseggend:

Oor die konsentrasiekampe het daar tot nou toe [1954 - JS] geen studie wat op wetenskaplike navorsing berus, verskyn nie. Wel het daar, tydens en na die Tweede Vryheidsoorlog, baie geskrifte oor die kampe verskyn, maar hierdie geskrifte neem in die reël die vorm aan van getuienisse van ooggetuies en is dus, ofskoon van waarde as bronne vir 'n studie oor die onderwerp, nie omvattend nie; daarby dra hulle 'n sterk persoonlike kleur en kan hulle geensins beskou word as die resultaat van studie met die doel om tot klaarheid oor die onderwerp te kom nie. Selfs dié artikels, brosjures en boeke wat nie deur persoonlike waarnemers geskryf is nie, beantwoord nie aan die doel nie, aangesien hulle meestal die werk is van partygangers wie se doel dit was om die een of ander standpunt te stel en te verdedig. Hulle dra dus in meeste gevalle die stempel van vooringenomenheid en is in elk geval nie op omvattende navorsing gegrond nie. Dat daar behoefte aan 'n objektiewe, omvattende studie oor die konsentrasiekampe bestaan, is dus duidelik (Otto, 1954:3; kursief bygevoeg).

Otto se doelwit met 'n objektiewe en omvattende studie het 'n dubbele betekenis: die diskwalifisering van die persoonlike dimensie van die konsentrasiekamp-ervaring as vooringenomenheid hoef nie sonder meer op 'n miskenning van die lyding van slagoffers neer te kom nie. Waarskynlik het Otto vertrou dat 'n statisties begronde oorsigtelike beeld van die konsentrasiekampgeskiedenis groter oortuigingskrag mag hê as dit aankom op die uiteindelike 
morele veroordeling daarvan. Statistiek moet (na die wêreld daarbuite) sterker spreek as subjektief beleefde insidente. Daarom word geen stem van die slagoffer self verneem (of vertrou) nie. Op die duur kan die persoonlike ervaring nie van die statistiek losgemaak word nie. As oorlogstatistiek en persoonlike trauma geskei bly, is die gevaar wesenlik dat die slagoffer getrivialiseer en dus weer getraumatiseer word omdat sy/haar ervarings of geringgeskat word in vergelyking met die groot geheel, of nie geglo word dat hy/sy dit alles deurgemaak het nie. Die statistiese feite oor die geskiedenis van konsentrasiekampe kan nie vertaal word in terapeutiese historiese optrede nie. Met die bekendwording van meer dagboeke, en met die metodologie wat sedert die Tweede Wêreldoorlog ontwikkel is om die ervaring van uiterste omstandighede te verstaan, is 'n studie oor Britse konsentrasiekampe in die sin van Anna Pawelczynska se Values and violence in Auschwitz (1979) of Tzvetan Todorov se Facing the extreme (1997) egter (en dus) nog uitstaande.

In die verwerking van die trauma van die Engelse konsentrasiekampe ${ }^{2}$ tydens die Anglo-Boereoorlog is verskillende strategieë van die politiek van herinnering gevolg. Die resultaat van hierdie strategieê was 'n bepaalde ritualisering en institusionalisering van die herinnering aan die trauma. Om te verstaan tot watter mate die trauma verwerk is, moet 'n mens hierdie strategieë onderskei. Toegang tot hierdie strategiee kan verkry word deur middel van geskrifte wat reaksies op die trauma van die konsentrasiekampe boekstaaf. Die strategieë wat onderskei kan word, het te make met die verloop en afloop van die gebeure self: meer as 39000 mense, waaronder meer as 26000 wit vrouens en kinders en meer as 13000 swart mense (mans, vrouens en kinders) het in hierdie kampe gesterf 3 . Die eerste bron van getuienis oor die trauma is dus die slagoffers self - in hierdie geval wit vrouens, en veral moeders van kinders (die swart bevolking

2 Die metodologie onderliggend aan hierdie interpretasie van die ervaring van trauma is hoofsaaklik geput uit Holocaust-studies. Kyk in hierdie verband Bergman en Jucovy (1982); Bettelheim (1979); Chany (1992); Danieli (1981); Des Pres (1976); Dimsdale (1980); Epstein (1979), Herman (1992); Marks (1993); Mitscherlich en Mitscherlich (1969); Pawelczynska (1979); Quindeau (1995); Tec (1986); Todorov (1997). 'n Belangrike punt om in hierdie verband te onthou, is die feit dat 'n mens 'n meta-taal nodig het om oor die grense van tyd en kulture heen oor trauma te kan nadink, en dit selfs te kan herken (ongelukkig meesal by nabaat) in die situasies waarin dit homself toon - 'n punt wat Antjie Krog goed begryp en verantwoord in haar Country of my skull (1998). In Meta-taal or trauma is egter nie noodsaaklik om - waar nodig, en so goed of gebrekkig as wat 'n mens gesosialiseer is empatiekc hulp aan traumaslagoffers te verleen nie. Met hierdie standpunt oor meta-taal is dit ook duidelik dat ek voorkeur gee aan die benadering van "Holocaust scholarship" bo "Holocaust literature" (vgl. Finkelstein \& Bim, 1998:87-100).

3 Die 26000 wit slagoffers kan verder gedifferensieer word: meer as 1600 was mans, meer as 4100 was vrouens, en meer as 20000 was kinders onder 14 jaar. Teenoor die meer as 39000 slagoffers van konsentrasiekampe het ongeveer 3800 mans aan Boerekant op die slagveld gesneuwel. Kyk Spies (1977:266). 
van destyds was - op enkele uitsonderings na 4 - ongeletterd, en het so goed as geen optekening nagelaat oor die trauma nie, terwyl mondelinge oorlewering tot vandag toe nog nooit nagegaan is nie5. Rassevooroordeel het in alle geval gemaak dat hierdie bron van ervaring tot baie onlangs onontgin gebly het ${ }^{6}$.) 'n Tweede bron van getuienis oor die trauma is die agtergeblewenes - wat in hierdie geval oorwegend manlik en wit is - eggenote en vaders. ' $n$ Derde bron is dié van waarnemers - in hierdie geval die uitvoerige optekenings van Emily Hobhouse, die Engelse teenstander van die oorlogspoging en noodleniger van die Boerefamilies. Histories is die ervaring en die verwerking van die konsentrasiekamptrauma deur die mans eerste geritualiseer en geïnstitusionaliseer - om twee redes: eerstens, omdat hulle strategie van traumaverwerking dié van die oorlewende is en daarom makliker en gouer openbare stem kry as dié van die gestorwe slagoffer wie se stem as 't ware herwin moet word uit die oorgelewerde berigte en dokumente (wat in die omstandighede na die oorlog nie algemeen toeganklik was nie), en tweedens omdat die samelewing destyds patriargaal georganiseer was (vgl. Cloete, 1992). Op hierdie ritualisering en institusionalisering van die herinnering het die optekenings van Emily Hobhouse ingespeel - deels as versterking van die algemene plig tot herinnering, deels as advokaat van die spesifiek vroulike stem oor lyding. En deur haar waarnemings en boekstawings kom die stem van die vroulike slagoffer uiteindelik (derdens) tot haar reg. Die uiteensetting wat volg, volg dan hierdie historiese patroon.

\section{Die skuld van die agtergeblewe mans: "Onze heldinnen"}

President M.T. Steyn gee die toon aan vir die eerste strategie van die verwerking van die konsentrasiekamptrauma. Hy is die dryfveer agter die oprigting van 'n monument vir die vroue en kinders wat in die konsentrasiekampe van die Britse

4 Volgens Warwick (1983) se studie is daar buite argiewe net twee gepubliseerde eerstehandse weergawes van die ervaring van swart mense uit hierdie era. Tot vandag toe is Sol Plaatje se Native Life in South Africa (1916) die bekendste getujenis van swart kant Warwick vermeld ook 'n M. Maxeke se "The Black Man's Side in the Transvaal War" wat in die Independent van 7 Desember 1899 verskyn het. Dric ander gepubliseerde bronne bevat weergawes van swart ervarings van die oorlog, naamlik die Transactions of the Aborigines' Protection Society (1899-1902), Mohandas Gandhi se Satyagraha in South Africa (1928), en S.M. Molena se The Bantu Past and Present (1920) (vgl. Warwick, 1983:216-217).

5 Emily Hobhouse maak gewag van "n "Mr. Alexander Tschwangtwe", 'n "Evangelist amongst his folk" wat haar op Reitz kom spreek het oor die wedervarings van sy mense tydens die corlog Kyk Van Reenen (1984:271-272), asook Spies (1977) en Warwick (1983)

$6 \quad$ Kyk die brosjure van die Oorlogsmuseum van die Boererepublieke (s.j.) wat na 1994 uitgegee is. Interessant dat Emily Hobhouse (1902) vermeld word as 'n bron, maar nie S B. Spies (1977) nie. 'n Mens vermoed dat ontkenning van die hele kwessie van swart betrokkenheid by die Suid-Afrikaanse Oorlog hier gekamoefleer word deur die aanbieding van sg. onlangse navorsing (veral Warwick, 1983) - wat ses jaar jonger is as Spies se studie. 
magte omgekom het en wat in 1913 onthul is. Die monument is gefinansier deur openbare skenkings. In 'n brosjure "geskrywe deur N.J. van der Merwe op versoek van die Monument-kommissie" (soos dit op die buiteblad aangegee word) word gestel dat die oprigting van die monument die vereffening van 'n ereskuld, die vervulling van 'n "begeerte by die manne [is ...] om 'n gedenkteken op te rig vir die heldinne, wat met hulle kinders hulle lewens feil gehad het" (Van der Merwe, s.j.:12). Die ontwerp vir die monument wat uiteindelik die openbare kompetisie gewen het, was dié van 'n Duitse argitek, Frans Soff. Sy ontwerp het 'n obelisk behels wat op 'n koppie buite Bloemfontein opgerig sou word. Voor die obelisk is 'n beeldgroep geplaas wat deur Anton van Wouw geskep is. Aan weerskante van die beeldgroep is 'n paneel wat episodes uit die oorlog uitbeeld.

In Van der Merwe se ongedateerde brosjure, geskryf tussen 1926 (die laaste datum waarna hy in die brosjure verwys) en 1941 (die jaar van sy dood), word die betekenis van hierdie monument in die raamwerk van 'n offer-metafoor geplaas. Pres. Steyn se toespraak by die onthulling van die monument word aangehaal. Daarin dui hy die sin van die monument onder meer soos volg aan: "As daar iemand is van wie Volk en Vaderland groot en swaar eise vorder, laat hierdie monument hom leer tot watter offers ware vaderlandsliefde bereid is" (Van der Merwe, s.j.:13). Die offer-metafoor word met ander metafore uitgebrei: vir Steyn is "die krag wat die swakke vroue sulke heldinne gemaak het" belangrik, naamlik 'n "vaste vertroue in die Almagtige [...] wat gesê het: 'Ek sal u nie begeef nie, ek sal u nie verlaat nie"" (Van der Merwe, s.j.:13). Hierdie "krag" as gevolg van 'n "vaste vertroue" is dan 'n "deug [...] wat deur hierdie monument verewig is" (Van der Merwe, s.j.:13). Verderaan in die brosjure word die regverdiging vir hierdie monument deur President Steyn ook gestel. Hy sou daarvan oortuig gewees het "dat geen inrigting ooit so tot die hart van die volk sal praat soos die stille welsprekendheid van 'n monument wat die triomferende martelskap [sic] van die moeders met hul kinders voorstel" (Van der Merwe, s.j.:18). Hierdie vroue word die apoteose van die held. Nogmaals Steyn:

As dit soet is vir die held om vir die vaderland te stry en met roem belade, hom op te offer vir vryheid, volk en vaderland, watter eerbied dwing die tere vrou nie af nie wat reeds self in die kloue van die dood liefling na liefling in die graf sien daal en tog! met fierheid haar hoof omhoog hou en haar eggenoot en seuns op die strydveld aanspoor om hulle nie oor haar te bekommer nie, maar in die stryd te volhard! (Van der Merwe, s.j.:6).

Hierdie monumentalisering van lyding hoef nie die wenkbroue te laat lig nie. Dit is volkome verstaanbaar as 'n strategie om die waardigheid van die slagoffers post factum te herstel. Die strategie is om van die slagoffer 'n held(-in) te maak. Dit beteken om van die persoon wie se individuele wil en begeertes deur militêre mag en wêreldpolitiek platgevee is, weer 'n persoon te maak wat self besluit tot opoffering. In die bloedige werklikheid van die oorlog is die slagoffer 
se lyding egter ongewil, meesal ook nie selfbewus nie en dikwels gepaardgaande met baie diepe vertwyfeling. Die slagoffer word van sy of haar subjektiwiteit gestroop - vir hom- of haarself beteken die lewe nie meer iets nie, en die band met ander mense word onder baie groot druk geplaas, indien dit nie heeltemal tot 'n las gemaak word nie (vgl. Pawelczynska, 1979:137-144). Die held van die agterna-verhaal, daarenteen, al gaan dié uiteindelik onder, se lyding is 'n gevolg van sy of haar wil en word gedra deur die bewussyn van die kontinuiteit van die gevolge van die keuse - na die dood van die held sal die vrugte van die held se keuse getuig van die historiese krag en korrektheid van die keuse. Waar die slagoffer nie 'n uitsig sou hê nie, sou die held bewus wees van 'n ideaal wat meer is as sy eie voortbestaan. Die slagoffer kan nie tot nut en diens wees nie, die held kan dien onder die ergste omstandighede. Die slagoffer kan nie voortleef nie, die held transendeer sy eie lewe.

Dit is dan ook die boodskap wat hierdie monument moet uitdra. Van der Merwe haal ds. G.D. Kestell se duiding van die sentrale beeldgroep ter verduideliking aan:

'n Vrouw zittende met haar kind stervende of dood op haar schoot en turende vóór zich henen. Is het wanhoop in hare ogen? Neen! De ogen doen de vrouw spreken: 'Mijn kind is dood, maar ik zal niet geheel en al uitsterven (non omnis moriar): Mijn volk zal niet uitgeroeid worden'.

Een andere vrouw staat naast haar en zij ziet ver in het verschiet: de toekomst van haar volk: het is alsof wij het woord van Mozes geschreven op haar kunnen toepassen: ' $\mathrm{Zij}$ hield zich vast als ziende den Onzienlijke' (Van der Merwe, s.j.: 20).

Die monument in sy geheel wil die volk figuurlik ophef uit die leed van die verlede, dit wil (in Van der Merwe se eie woorde) "uit die vlakke veld van die alledaagse lewe tot verhewener en reiner sfere op[...]roep" (Van der Merwe, s.j.: 18-9). Die hele duidingstrategie is daarop gerig om die smart van die oorlog te transformeer na triomf. Vandaar die keuse van die gedenknaald - die vertikale struktuur wat in die ooptes en die oneindige inwys. Maar in die Van der Merwebrosjure word die smart van die oorlog ook onderspeel. Dit word in enkele statistiek en verwysings weergegee (in 6 uit 52 bladsye). Vir meer kennis hieroor word die leser/besoeker verwys na Emily Hobhouse se oorlogsdagboek, The brunt of war and where it fell. 'n Verdere 10 bladsye van die brosjure word in beslag geneem deur 'n beskrywing en verduideliking van die monument self, 8 bladsye deur 'n lewenskets van pres. M.T. Steyn, en die laaste 23 bladsye is 'n huldeblyk aan Emily Hobhouse. Wat moet 'n mens hieruit aflei? Ek waag 'n antwoord: manlike ongemak in die aangesig van soveel leed. In alle geval iets van die universele skuld van die oorlewende wat met die hulp van 'n hermeneutiese strategie - dié van die transformasie van die slagoffer na die held 
- besweer word? . Die manlike strategie het bedoel om 'n selfbeeld te herstel hoofsaaklik die selfbeeld van die man wat ' $n$ traumatiese verlies ervaar het, en in die tipiese skuldbelewenis van die oorlewende 'n beeld projekteer van sy verlore lewensgenote ten einde hulle waardigheid in sy belewenis van homself en van die herinnering aan hulle te herstel. Hierdie strategie beweeg hoofsaaklik in die ruimte van die onmiddellike en intieme verwantskap. Dit reik nog nie verder na ander mense en die wêreld van mense in die geheel nie. Hierdie verdere dimensie aan die strategie van traumaverwerking is deur Emily Hobhouse verleen.

\section{Die vroulike en feminisfiese stem: "Brokenhearted womanhood, perishing childhood"}

Anton van Wouw se oorspronklike maquette vir die Vrouemonument het Emily Hobhouse nie bevredig nie. Sy is versoek om so taktvol as moontlik toesig te hou oor die maak van die uiteindelike beeld. Vir hierdie doel is Van Wouw na Rome gestuur, en daar het hy onder die wakende oog van Emily Hobhouse die beeld voltooi. Op haar aandrang moes Van Wouw sy oorspronklike konsep wysig. Sy het 'n insident wat sy meegemaak het by Springfontein - "the picture photographed on my mind can never fade", het sy later in 'n memoir daarvan geskryf (Van Reenen, 1984:111) - aan Van Wouw voorgehou:

[...] I was called to see a sick baby. The mother sat on her little trunk with the child across her knee. She had nothing to give it and the child was sinking fast. I thought a few drops of brandy might save it, but tho' I had money there was none to be had. [...] There was nothing to be done and we watched the child draw its last breath in reverent silence.

The mother neither moved nor wept. It was her only child. Dry-eyed but deathly white, she sat there motionless looking not at the child but far, far away into depths of grief beyond all tears. A friend stood behind her who called upon Heaven to witness this tragedy ...

The scene made an indelible impression upon me. [...] Years after, when Mr. van Wouw came to Rome to carry out the monument, [...] I described to him this scene as it seemed to me to hold in itself the centre and core of the tragedy: broken-hearted womanhood, perishing childhood (Van Reenen, 1984:112).

7 Iets van hierdie ongemak blyk uit die bekende gedig van Totius, "In die kamp", uit sy eerste bundel van 1908, Bij die monument. Vir 'n bespreking van hierdie gedig, en 'n vergelyking daarvan met 'n gedig uit die Duitse bundel volksgedigte, Des Knaben Wunderhorn, kyk Snyman (1996:198-204). Ongemak was egter nie die enigste soort reaksie aan manlike kant nie Louis Leipoldt (1980) se gedigte oor die leed van die kampe bestryk ' $n$ breer register: daar is byvoorbeeld die bitter ironie en protes, en die gevolglike stem wat vir die vrou opgeneem word in Vrede-aand (1980:35), die deurleefde verleentheid oor eie smart in "Oom Gert vertel" (1980:5-11), en die empatie van "Aan 'n seepkissie" (1980:30). 
Emily Hobhouse het ook uitvoerig berig oor Anton van Wouw se vordering onder haar toesig. Ek haal haar uitvoerig aan, omdat haar beskrywing en oordeel veelseggend is:

I [...] went to criticize his first clay model at his desire. I did not like it and had to tell him so. He is too easily satisfied and will have, I think, to rub shoulders a bit with the sculptors here who are capable of expressing their ideas in stone and bronze - and of composition - and are not content with mere portrait work such as Mr. Van Wouw has chiefly done.

It is a great subject - a grand opportunity - and since he has appealed to me for help I shall do my utmost to keep him up to the pitch and not let him be satisfied too easily. But of course he may not have greatness in him. I do not yet know. I always thought only Rodin could treat that subject worthily (Van Reenen, 1984:513).

Haar finale oordeel het sy uitgespreek in 'n brief van 5 April 1912:

The standing woman seems to me very good, full of feeling and the sitting mother is better, though still far from satisfactory. The child on her knee is nicely modelled though still only appears to me a sleeping child and neither sick nor dead. I suggested he should get leave to go to a hospital and study one or two dead figures (Van Reenen, 1984:513-514),

en (in 'n memoir):

Mr. Van Wouw as you know reproduced the scene in bronze. Had he seen it with his own eyes, the child would have borne more directly the aspect of emaciation and death (Van Reenen, 1984:112).

Wat is die punt omtrent die Vrouemonument? Dit is duidelik dat die amptelike interpretasie (van Van der Merwe) nie die volle verhaal vertel nie. Moet 'n mens dit nou beskou as 'n onsuksesvolle poging om 'n monument op te rig?

As ons Emily Hobhouse se oordeel aanvaar dat Van Wouw onbeholpe was, omdat hy nie lyding kon uitbeeld soos Rodin dit sou gedoen het nie, het Van Wouw se uiteindelike beeld tog baie goed ingepas by die kulturele agtergrond van die mense vir wie hierdie beeld bedoel is. Ons moet in gedagte hou dat Rodin se Burgers van Calais en sy Balzac-beeld hoogs omstrede in Frankryk was, en sy moontlike uitbeelding van die lyding van Boerevrouens en -kinders kon dalk glad nie aanvaarbaar gewees het vir 'n destydse Afrikaanse publiek nie. 'n Onderliggende rede vir Emily Hobhouse se oordeel oor Van Wouw se werk kan egter ook 'n konflik van belange wees. Hierdie konflik kon gelê het tussen Emily Hobhouse se aandrang om die slagoffers te gedenk en die Boere se behoefte aan 'n monument. 'n Toutrekkery het as 't ware ontstaan. Kort en op die punt af: aan wie het (die nagedagtenis van) die gestorwenes behoort? Waar moet 'n mens hulle in die geskiedenis plaas? Aan die kant van die Boere (en 'n 
lokale - sigbare en bekende - stryd), of aan die kant van die mensheid (en 'n universele onsigbare en onbekende stryd)? Waarvoor presies het die slagoffers gesterf? Wat is die sin van hulle dood?

Vir haar tyd was Emily Hobhouse 'n uiters geëmansipeerde vrou, en alhoewel sy uit 'n baie godsdienstige agtergrond gekom het (haar pa was 'n Anglikaanse predikant), was sy self 'n vrydenker. Sy het die ideale van die Verligting onderskryf, naamlik universele en gelyke vryheid vir alle mense, sy was 'n selfverklaarde pasifis (Hobhouse, 1923:xxi), 'n Britse patriot wat haar regering onverbiddellik gekritiseer het oor sy vergryp aan menseregte 8 . Haar liberale oortuigings het haar gedring om empatie met mense oor nasionale grense heen te hê, en haar eie nasie se maghebbers moreel te veroordeel vir hulle magsmisbruik. Sy het geen simpatie met politieke noodsaak gehad nie. Dit is bekend hoe sy noodleniging tydens en na die oorlog onderneem het, ten koste van haar eie waardigheid en gesondheid. Miskien minder bekend, maar juis belangrik vir 'n post-apartheid Suid-Afrika, is die feit dat sy 'n hele veldtog geloods het vir vergelding aan die slagoffers aan Boerekant. Sy het nie alleen kos, klere, ploegspanne en saad vir terugkerende Boerefamilies georganiseer nie, maar vrou-alleen die eerste Waarheids- en Versoeningskommissie in Suid-Afrika op die been gebring. Sy het beëdigde verklarings by veral Boerevroue afgeneem, en dit laat publiseer in 'n bundel (eers in The brunt of war and where it fell in 1902, en in 1924 in War without glamour, or, women's war experiences written by themselves, 1899-1902) ten einde die Britse publiek en die Britse regering onder die indruk te bring van die noodsaak van een of ander vorm van vergelding - ten minste finansiële vergoeding vir die slagoffers en veroordeling, in die openbaar, selfs in 'n hof, van die militêre amptenare van die staat wat verantwoordelik was vir hierdie wandade.

Filosofies gesproke, is daar 'n baie interessante strategie aan die werk by Emily Hobhouse. Sy deurbreek die etniese grense wat politiek so maklik trek om morele eise. In die politiek van die openbare belang is dit maklik om gelyke regte te billik vir almal wat met die openbare belang en sy grense identifiseer. Wat buite hierdie grense val, is die Ander, wat nie op dieselfde regte kan aanspraak maak as die "ons" van die openbare belang nie. In 'n konfliksituasie neem die Ander altyd die gestalte aan van die vyand, die "hulle", en dié het geen belang wat deur "ons" behartig hoef te word nie. Om morele voorspraak vir "hulle" te doen, word gou as verraad gebrandmerk. Maar om morele voorspraak vir die Ander te doen, is om die universaliteit van die morele eis te handhaaf en in 'n sekere $\sin$ is dit presies die potensiaal van die eis om universeel te wees, wat dit in hierdie geval so moreel sal maak. Dit gaan vir Emily Hobhouse sinode in 1903. Kyk Van Reenen (1984:318-320). 
daarom dat die menslikheid van die "ons" in die "hulle" erkenning kry, en waar dit gebeur, dat die geweld deur die "ons" uitgeoefen op die "hulle" ook herken sal word en daarom ook vermy sal word. Hierdie punt teen 'n politiek van noodsaak kan gestel word deur 'n politiek van herinnering. Sy mobiliseer "the universality and similarity of experience" (Hobhouse, 1924:5) teen die verstomming van slagoffers tot 'n "sprakelose massa verwarde ellende op ['n] aaklige agtergrond" (Hobhouse, 1923:xxii) - 'n "selfbedrog" (Hobhouse, 1923:xxi) wat die voortsetting van oorlog en lyding makliker maak. "Geskiedskrywers het te lank reeds die lof van kryg en krygsliede verkondig en slegs met een of ander algemene gesegde die oorlogsmarte van diegene wat buite geveg gestel is, verbygegaan. Waarskynlik skiet moderne geskiedverhale hierin nog meer tekort [sic] as die ou of Middeleeuse skrywers" (Hobhouse, 1923:xxi).

Deur haar te beroep op "the universality and similarity of experience" maak Emily Hobhouse ook die skeiding tussen huishoudelike politiek en koloniale politiek - so tipies van die Britse imperiale opset (vgl. Arendt, 1986:228-234) tot niet. As Britse patriot wat "in elke vreemde volk 'n moontlike nasie sien en daarom oortuig is dat geen nasie die reg het om sy wette aan vreemde volke op te dwing nie" (Arendt, 1986:229) eis Hobhouse dat hierdie gesindheid ook konsekwent van die Engelse openbare lewe af tot in die administrasie van die Engelse kolonies moet geld. Teen hierdie eis het die koloniale amptenaar hom altyd verweer, en sy houding is uiteindelik geïnstitusionaliseer in 'n soort subklousule van die Engelse sosiale kontrak waarin die administrasie van koloniale besittings uitgedefinieer is uit die gelding van 'n Britse algemene moraliteit soos voorgestaan deur " $n$ onervare meerderheid". Die mag om te regeer is gevolglik in die kolonies aan ' $n$ "minderheid van eksperte" oorgelaat (Arendt, 1986:229). In haar morele universalisme bevraagteken Emily Hobhouse hierdie subklousule van die Engelse sosiale kontrak - tot die verontrusting van 'n aansienlike deel van die Engelse publiek, politici en koloniale amptenare.

Om hierdie rede beskou Emily Hobhouse die Vrouemonument as iets unieks. Aldus haar, en in terme van 'n woordeskat wat lank na haar eers gekom het, is dit die eerste kontramonument ${ }^{9}$. Weliswaar gebruik dit nog steeds die simbole van die monument: die obelisk, die verheffing in die hoogte in. Maar waar die gebruiklike "verheerliking van leër en seemag" sy hoogtepunt bereik in die "begrafnis van die "Onbekende Krygsman", is die Vrouemonument enig in sy soort (tot op daardie stadium) om hulde te bring aan "die siviele martelare van die Oorlogsgod" (Hobhouse, 1923:xxv). Dit moet sonder woorde spreek vir diegene wat sonder stem in die oorlog was.

9 Vir 'n uitvoerige uiteensetting van die opkoms en die funksie van die kontramonument, kyk Young (1993:27-48). 
As Emily Hobhouse egter die Britte gemaan het om bo hulle etniese grense menslike lyding by ander te herken, laat sy nie na om die Boere daaraan te herinner dat die betekenis van hulle lyding ook verder strek as hulle eie lokale geskiedenis nie. Die hoogtepunt van haar toespraak vir die onthulling van die Vrouemonument bevat die volgende woorde:

Your visible monument will serve to this great end - becoming an inspiration to all South Africans and to the women in particular.

$[\ldots]$

For remember, these dead women were not great as the world counts greatness; some of them were quite poor women who had laboured much. Yet they have become a moral force in your land. [...]

And their influence will travel further. They have shown the world that never again can it be said that woman deserves no rights as Citizen because she takes no part in war. This statue stands as a denial of that assertion. [...]

$[\ldots]$

My Friends: Throughout the world the Woman's day approaches; her era dawns. Proudly I unveil this Monument to the brave South African Women, who, sharing the danger that beset their land and dying for it, affirmed for all times and for all peoples the power of Woman to sacrifice life and more than life for the common weal (Van Reenen, 1984:406-407).

Hobhouse plaas die betekenis van die lyding van die Boerevroue en -kinders in 'n breër raamwerk. Filosofies is dit niks nuuts wat sy doen nie. Sy veralgemeen die lokale Boerevrou tot 'n simbool van die Universele Vrou se stryd om erkenning. Die Boerevrou maak deel uit van 'n geheel wat haarself transendeer. Die betekenis van haar stryd is dat sy in ' $n$ bepaalde en afgeleë wêrelddeel 'n slag slaan vir iets waarmee ander vroue op ander maniere in ander dele van die wêreld besig is. Sy lewer ' $n$ bydrae tot die solidariteit van die mensdom teen mag wat lyding as afskryfbare prys vir meer mag sien. Die feit dat die relevansie van die Boerevrou se stryd meer as bloot lokaal is, gee daaraan 'n spesifieke morele dimensie. Daarom is daar 'n les vir iedereen uit hierdie stryd te leer. Hierdie stryd spreek oor die politieke verdeling tussen Boer en Brit, tussen wit en swart heen. Dit is egter presies hierdie les wat die Britte (of drie vyfdes van hulle [vgl. Hobhouse, 1923:xix]) nie wou leer nie, asook latere Afrikaanse bewindhebbers. Emily Hobhouse se pleidooie vir hierdie lesse uit die verlede ter wille van die "hoër bestuur van volkere" was vir Afrikaners tydens die apartheidsjare 'n verleentheid. Haar interpretasie van die lyding van Boerevroue en -kinders is gesensureer. In sowel Van der Merwe se aanhalings uit haar onthullingstoespraak as die 1963-uitgawe daarvan is die volgende passasies (in kursief aangehaal) weggelaat: 
In your hands and those of your children lie the power and freedom won; you must not merely maintain but increase the sacred gift. Be merciful towards the weak, the down-trodden, the stranger. Do not open your gates to those worst foes of freedom - tyranny and selfishness. Are not these the withholding from others in your control, the very liberties and rights which you have valued and won for yourselves?

Many nations have foundered on this rock. We in England are ourselves still but dunces in the great world-school, our leaders still struggling with the unlearned lesson, that liberty is the equal right and heritage of every child of man, without distinction of race, colour or sex. A community that lacks the courage to found its citizenship on this broad base becomes a 'city divided against itself, which cannot stand'.

\section{$[\ldots]$}

We too, the great civilized nations of the world, are still but barbarians in our degree, so long as we continue to spend vast sums in killing or planning to kill each other for greed of land and gold. Does not justice bid us remember today how many thousands of the dark race perished also in Concentration Camps in a quarrel which was not theirs? Did they not thus redeem the past? Was it not an instance of that community of interest, which binding all in one, roots out racial animosity? [...] (Van Reenen, 1984:406-407.)

Deur die plaaslike geskiedenis in 'n wêreldperspektief te plaas, wil Emily Hobhouse sin gee aan die trauma van die Anglo-Boereoorlog. Soos die manlike perspektief op die gebeure, span sy ook die modernistiese idee van die held in, maar met 'n verskil. Die modernistiese idee van die held behels die gedagte van 'n mens wat in deurslaggewende situasies meer as blote eie belange kan laat oorwin. Sulke mense gaan dikwels fisies onder, soms teësinnig, maar 'n beginsel vir tyd en ewigheid word deur hulle optrede gevestig. Hulle word voorbeelde, daar is iets "algemeen mensliks" aan hulle. Hierdie siening van die held word maklik manlik chauvinisties - soos blyk uit die visuele uitbeelding van die klassieke held wat die manlike anatomie bevoorkeur het. Die heldefiguur word die uitbeelding van 'n voltooide sege wat blywend moet inspireer, of dit is ' $n$ uitgebeelde ideaal wat teruggevind kan word in bepaalde historiese konfigurasies. Hierteenoor verkies Hobhouse om nie die klem op kragdadigheid en oorwinning te lê nie, maar om eerder die ambivalente begrip van die sublieme ${ }^{10}$ in te span, waarin oorweldigende magte én broosheid gelyktydig aanwesig is en waarin die uiteinde van die konflik nie ' $n$ uitbeeldbare sege is nie. Hiervoor haal sy self George Elliot aan, wat gesê het: Lyotard daaraan heg. Kyk Lyotard (1991) en Pries (1989.) 
Tragedy must represent irreparable collision between the individual and the general. It is the individual with whom we sympathize, and the general of which we recognize the irresistible power (Van Reenen, 1984:112).

Die sublieme is gelee in die naklanke van die onuitspreeklike in begrippe soos "irreparable" en "irresistable" in die aangehaalde gedeelte. Dit dui op die teenwoordigheid van 'n oorweldigende mag wat nie in gewone begrippe ten volle beskryf kan word nie. Maar die ervaring van hierdie mag, ofskoon beangstigend, is iets wat interessant is, en esteties intrigerend - veral in die re-presentasie daarvan. In die belewing van die re-presentasie van 'n botsing tussen ' $n$ brose individu en 'n oorweldigende mag is ' $n$ bepaalde morele bevrediging die resultaat: ten spyte van selfs 'n moontlike fisiese ondergang van die individu, bly die herinnering van ' $n$ morele grootsheid oor - die individu kan in sy of haar wil nog nee sê vir die magte. Die mens se weiering om die magte te aanvaar deur dit te regverdig as die beloop van die wêreld, is 'n moment waarin die mens die omvang van die magte transendeer. Die kenmerkende van hierdie klassieke opvatting van die sublieme, ontleen aan Burke en Kant (vgl. Crowther, 1993:116 e.v.) is dat dit 'n ambivalensie volhou: die brose morele grootsheid van die mens is net begrypbaar in die aangesig van die fisiese grootheid van die magte waarmee hy of sy gekonfronteer word (vgl. Pries, 1989:27-30). Streng gesproke bly die sublieme held se verhaal onvoltooi, die oorwinning uitgestel, die lyding onoorkome in die representasie.

In hierdie sin is die Vrouemonument subliem. En volgens Emily Hobhouse is dit gepas - ons simpatie moet by die slagoffer lê. Maar die ambivalensie van die sublieme kan ook maak dat daar in eensydigheid verval kan word: smartvratery of bombasme. Hierteen probeer Emily Hobhouse wal gooi as sy die Boerevrou se lyding voorhou as 'n navolgenswaardige simbool, nie net vir die agtergeblewenes van die plaaslike oorlog in Suid-Afrika nie, maar vir die hele wêreld. Die betekenis van die Boerevrou se lyding gaan haar eie historiese begrensing te bowe.

\section{Die stem van lyding self: "de wereld schynt nu geheel ledig voor my"}

Emily Hobhouse se strategie vir singewing verskil nogal ingrypend van dié van die manlike woordvoerders van die slagoffers van die Anglo-Boereoorlog. Maar dit kom baie na aan wat die vrouens self oor hulle lyding in die situasie te sê gehad het. Emily Hobhouse wou dat die lyding self, eerstehands, spreek. Dit moes die werklikheid van oorlog by mense tuisbring wat gedink het oorlog is die gulde geleentheid om roem en eer vir "Queen and Country" te verower. Daarom het sy foto's van kampslagoffers laat neem om in Brittanje te publiseer. Maar die waardigheid van die slagoffers moet so ver as moontlik eerbiedig word. Daarom is hulle nie in hulle volle gedepriveerdheid gewys nie. Anders as foto's uit die Tweede Wêreldoorlog van kinderslagoffers, is die slagoffers van 
die Anglo-Boereoorlog vir die foto's opgestel in 'n omgewing wat nog iets huisliks oorhou.

Die Boerevroue het veral in die Bloemfonteinse kamp ook gebruik gemaak van die dienste van beskikbare fotograwe om as 't ware rekords te hou van hulle kinders ter wille van hulle mans in die veld of in ballingskap Die tragiek van hierdie foto's is dat hulle geneem is van die kinders as dié reeds dood was - 'n laaste herinnering wat vasgelê word, maar ook slegs as die kinders nie uitgeteer was nie. Die beste herinnering onder omstandighede moes van die slagoffer bewaar gebly het. Soos 'n mev. M. du Toit op 22 Oktober 1901 uit die konsentrasiekamp op Aliwal-Noord aan haar man skryf oor hulle twee gestorwe kinders, Naomi en Fransie:

[O]ns heef ons laat afneem ik zal u een van de portretten stuur maar ik denk het zal $u$ meer verdriet doen als goed ik heb Fransie laat afneem toen hy dood was het is zoo mooi hy lyk of hy slaap, Naomi was te vervallen, ik wou hen graag eerder laat neem heb maar zy had zeren aan haar gezicht en voor dat het gezond was is zy dood (Oorlogsmuseum van die Boererepublieke ms 5592/12).

Die briewe van vroue uit die konsentrasiekampe gee egter die meeste insig oor hulle eie gewaarwordings en hulle eie sienings van hulle lyding. 'n Mens kry nie baie feite oor die toestande in die kampe uit hierdie briewe nie - daarvoor het militêre sensuur gesorg. Daarby moet 'n mens in gedagte hou dat die Boerevroue hoofsaaklik uit 'n agrariese kultuur kom. Briefskryf was beperk tot elementêre kommunikasie oor waar hulle hulle bevind en hoe hulle welstand is. Welsprekende betoë oor hulle toestand en ervarings was nie die reël nie. Die oorgrote meerderheid van die briewe vertoon dieselfde stereotiepe vorm. Die retoriek oorheers dikwels die inhoud. Gewoonlik is die eerste bladsy van die voubrief met swart omraam, sodat die geadresseerde geweet het hy (meesal hy) ontvang treurige nuus. Die grootste deel van die brief word beslaan deur allerlei formaliteite en konvensionele inligting, en die eintlike nuus kom in die laaste paragraaf - die nuus van die oorlye van 'n kind of ander familielid. Die briewe klink min of meer almal so:

Mij zeer geliefde en nooit vergete man,

Ek zet mij neder $u$ te melde dat het ons alle nog zeer goed gaan, hopende diezelfde van uw te hoor. Baie dankie vir uw laatste brief wat ons twee maande bereik het nadat dit gepos is. (Alternatiewelik: Ek het nog niks van u verneem sedert ..., maar het van Oom X gehoor wat $u$ laats gezien het bij ...) Het jij noch genoeg geld? Daar is nie baie nieuws uit die kamp nie. (Hierop volg gewoonlik 'n uitvoerige mededeling oor die wel en wee van familie en bekendes. In die heel laaste paragraaf word die eintlike nuus oorgedra:) ' $n$ Week gelede is ons lieve zoon/dochter/kinders/moeder/vader 
na 'n verschrikkelijke lijding dood aan die influmatie. Nou groet ek met die pen maar nooit met die hart, en met een kus der liefde.

Uw nooit vergetende vrouw/moeder/tante,

Mev. Y (voorletters en van).

Die meeste van hierdie soort briewe het uitgekom by ballinge in St. Helena, Ceylon, Indië en in Bermuda, en is daar deur die geadresseerde bewaar én weer teruggebring na Suid-Afrika, terwyl baie minder briewe van ballinge aan konsentrasiekampinwoners bewaar gebly het. Dit op sigself is veelseggend. Afgesien van die feit dat lewensomstandighede in die ballingkampe beter was as in die konsentrasiekampe, wat die behoud van die briewe van die vrouens aan die mans kan verklaar, is daar ook ' $n$ ander rede. Die brief is die man se enigste kontak met die res van sy hele lewe - sy gesin, sy sosiale en ruimtelike omgewing. Die relaas van die wel en wee van die familie is eksistensieel uiters belangrik vir die persoon wat van sy normale en volle lewe afgesny is. Dit herskep vir hom sy sosiale geografie, en hy kan dit oor en oor beleef in die lees van die brief. By gebrek aan enige ander voorstelling van die lewe voor die oorlog en voor die konsentrasie- en ballingkamp, is die brief vir sowel die skrywer as die leser 'n poging om hulleself te herkonstitueer as subjekte in ' $n$ ander ruimte. Die brief word die teenmiddel vir die ervaring van ontworteling. Aan die een kant is dit die tragiek van hierdie briewe: dit is al wat vir mense oorgebly het - daardie miniskule vryheid om te praat oor 'n wêreld wat nie meer is nie in 'n omgewing waar die mense nooit tuis kan raak nie. Aan die ander kant is dit (onwetend) die wonder van hierdie briewe: hierdie herskepping in die gedagtes van die vooroorlogse omgewing het hierdie omgewing, en daarom hulle band daarmee, en ten diepste hulleself, aan die lewe gehou'1.

Die tragiek word vir die naoorlogse leser van hierdie briewe skerper as 'n mens agterkom hoe veral twee tekste uit Job aanhoudend in hierdie briewe voorkom, naamlik "Die Here het gegee, en die Here het geneem, die Naam van die Here

11 Hierdie rol van herinnering in die traumatiese situasie, as teenwerking van die vernietigende effek van trauma op die sinvolle verbintenisse met die wêreld, word verder bevestig deur 'n feit wat prof. Elizabeth Lickindorf, tans van die Departement Engels aan die Universiteit van Port Elizabeth, my meegedeel het. Van haar familie was in Duitse konsentrasiekampe in Pole tydens die Tweede Wêreldoorlog. Toe hulle nog pakkies van die wêreld buite die kamp kon ontvang, het iemand 'n kookboek aan die familielede in die kamp gestuur. Die familielede in die kamp skryf tot vandag toe hulle oorlewing aan hierdie kookboek toe: as dit etenstyd was, en daar was niks of byna niks om te eet nie, het hulle dic kookboek uitgehaal, ' $n$ resep vir een of ander gereg voorgelees, en die res van die toehoorders het dan op die resep voortgeborduur en vertel hoe sy/haar ma, of wie ook al, dit of dat gedoen het om die smaak te verbeter of om die resep te laat slaag. Die punt is duidelik: in hulle gedagtewerreld het die slagoffers hulle gespysig aan die herinneringe van hulle gelukkige verbintenis met 'n wêreld buite en anderkant die kamp. 
sy geloofd", en "Sal ons die goeie uit die hand van die Here ontvang en nie ook die slegte nie?" Die aanhaling van hierdie tekste is 'n gevolgtrekking wat gemaak word na die konstatering van die verskrikking van die oorlog as 'n straf deur die Allerhoogste vir ongenoemde sondes. Die onderliggende teologie van hierdie soort opmerkings is ongetwyfeld vroom, maar fatalisties.

Enkele briewe gee blyke van 'n bewussyn van dié soort offervaardigheid wat pres. Steyn as tiperend van die houding van die vroue beskou. Die skryfster moedig haar man of familielede aan om ten spyte van die berigte oor die verskriklike toestande in die kampe aan te hou veg vir die vryheid van die vaderland. Iets van 'n versetgees blyk ook uit die dagboek van Maria Fischer, waarin sy haar ruimskoots van 'n snydende ironie oor die Engelse Ryk bedien:

As kind het ek nooit veel van beskawing gehoor nie. Later, nadat ons land so ryk aan goudvelde geword het, is daar gesê dat ons onbeskaaf is en dat Engeland ons moes reghelp. Hoe dit alles gedoen sou word, kon ek nie begryp nie, maar weet dit nou, helaas, alte goed - en ek vrees dat dit maar die begin van my skooltyd is. Daarom gaan ek probeer om alles wat tot beskawing van die boerevroue nodig geag word, op te teken. As dit my geluk, kan dit nog vir die een ander onbeskaafde skepsel tot nut wees (Fischer, 1964:5-6).

Die slagoffer wat haar stem só kon laat hoor, was egter die uitsondering.

Ook 'n uitsondering, maar aangrypend, is die reeks briewe in die Oorlogsmuseum van die Boererepublieke in Bloemfontein van die reeds genoemde mev. M. du Toit uit die Aliwal-kamp. In 8 briewe aan haar man, van 22 Oktober 1901 tot 1 Mei 1902, konfronteer hierdie vrou haar eie leed. Saam met die gebruiklike herkonstituering van die sosiale ruimte roep sy geleidelik die gebeure van die dood van haar twee kinders, Naomi en Fransie, terug. Afgesien van haar eie twee kinders, wat onderskeidelik op 12 en op 18 Augustus 1901 aan die "influmatie" (d.i. waarskynlik skarlakenkoors) oorlede is, kom 'n mens agter uit die reeks briewe dat daar meer as 33 mense, waarvan meer as 20 kinders was, uit haar vriende- en familiekring in hierdie tydperk gesterf het. Die briewe spreek van 'n behoefte om te skryf (die kantaantekeninkies in die tweede en derde brief maak verskoning vir die handskrif, omdat sy op 'n plank of ' $n$ kussing moet skryf) om uitdrukking aan gewaarwordings te gee, van 'n opstandigheid wat onder die oppervlak lê oor die dood van haar geliefdes, 'n behoefte om vertroos te word: "de wereld schynt nu geheel ledig voor my het is soms ondragelyk en wie weet hoe lang nog" (ms 5592/12), "nooit zal het weer wezen wat het was" (ms 5592/18), en daarom - "de Heer maak my slechts stil en tevreden, vergeet niet voor my te bidden om geduld en tevredenheid" (ms $5592 / 13$ ). Wanneer daar die dreiging van die oorweldigende lot is, roep sy klein besonderheidjies van haar kinders en van haar familielewe op om die gevoel van futiliteit te besweer: "o hoe wensch ik somtyds dat myn kleinen nog by my is het 
is tog alles zoo ledig en stil Naomie was de leven van ons huis zy was altyd opgeruimd Fransie is maar de stille onskuldige liefling gebleven" (ms 5592/13)

Die eerste brief begin met die mededeling aan haar man van die dood van Naomi en Fransie, maar daar is nog 'n huiwering om die volle verhaal te vertel. Eers in die derde brief - die langste van al die briewe - word die doodsoomblikke in besonderhede gekonfronteer:

Ach! als ik nog aan de dagen denkt toen ons kleinen dood is, dan sidder ik, want het was toen zoo als in de Schrif staat Een stem is gehoord in Rama van veel geween Rachel beweende hare kinderen omdat zy niet zyn, er was byna geen tent of daar was ziekte en dood $O$ ik zal het nooit vergeet niemand die het niet gezien heeft kan er een denkbeeld van maken, hier is veel bitter tranen gestort en word nog daaglyks gestort de stem van lieve Fransie hoor ik nog gedurig, hy was tog zoo beter en toen dacht ik dat ik hem behouden zoo kwam de dood en nam hem weg hy moest net zachte kost krygen, hy heeft altyd vleesch gevraagd en die moest hy niet eten, Ach die zachte swakke stemmetje klink nog altyd in myn oren (ik het zoo honger, hoe heb ik hem alles beloofd als hy beter is want hy kon het niet eten heeft de Dokter gezegd. Naomie heeft nooit iets anders als water gevraagd twee dagen voor haar dood heeft zy niets gevraagd ik moes haar alles geven haar oogen heeft zy nooit oop gemaak als ik haar zeg maak tog oop die oogies en kyk hier is mama dan maak zy dit een weinig open maar sluit het dadelyk weer Fransie heeft het nooit eers gemerkt dat zy dood is, toen hy beter was heb ik voor hem koekies gekocht toen zeg hy aan Mama gaan geef aan Dingie ook een, naderhand zeg weder toe ouma neem die een en gaan geef het aan haar de nacht voor dat hy dood is zeg hy aan my hy wil naar de tent gaan Dingie is zoo alleen daar, zy was in de tent ziek en by mama in de huis twee dagen voor haar dood heb ik haar ook in huis gebragt met de hoop het zal beter gaan, de Heer heeft het goed gedacht om hen zoo kort na elkander te neem want zy was zoo aan elkander verbonden dat de een nooit zonder de ander blyven kon, ik heb hen in een graf gelegd en als de Heer my spaard en wy gaan weder terug zal ik hen hier kom weg neem, arme oude vader hy schryf in elken brief van hen, hy gevoeld het zeer, hoe dat hy hen missen zal als hy terug komt $\mathrm{O}$, de Heer maak my stil en te vreden onder alles en leert my gelovig zeggen Vader uw wil geschiede (ms $5592 / 14)$.

Die feit dat hierdie terugroep van die sterwensoomblikke van haar kinders as ' $t$ ware ingelei word met ' $n$ verwysing na die Bybelse Rachel by Rama (vgl. Jer. $31: 15$ ), is om twee redes belangrik. Die eerste is dat dit blyke gee van 'n doelbewuste deurdink van die trauma. En die deurwerk is nie 'n geval van singewing deur identifikasie met en partisipasie aan die lotgevalle van 'n erkende, vroeër geval en, uiteindelik, 'n verheffmg tot die hoë status van gesanksioneerde offerande nie (soos wat in Kestell se duiding van die oorlogstrauma, met die beroep op Horatius se non omnis moriar die geval is). Hierdie vergelyking met Rachel van Rama is iets anders. In die briefskryfster se 
verwysingswêreld is die Rachel van Rama weliswaar 'n gesanksioneerde figuur - omdat dit in die Bybel staan, moet dit - ook die historiese - waarheid wees. Daarom is sy 'n presedent. In hierdie sin is die vergelyking met Rachel 'n poging om die oorweldigende van die trauma te besweer deur die self aan 'n presedent te herinner, en so vas te hou aan hoop. Die briefskryfster suggereer: ander het vantevore iets soortgelyks beleef, en het die ervaring oorleef. Daarmee weier die skryfster om die trauma in sy persoonlike sowel as kollektiewe dimensie as só uniek te sien dat dit onbeskryflik en onbegryplik word, en dat die lydende mens daardeur radeloos gelaat word. Die vind van 'n presedent - 'n greep van die herinnering - stel haar in staat om haar lyding te verwoord as 'n verslag aan haar man. En as sy dit een keer meegedeel het, om dit met haar man te deel, is die ervaring daarmee ook na buite gebring, en afgehandel ${ }^{12}$.

Hierdie element van vashou aan 'n gesanksioneerde ander maar vergelykbare geval ten einde die trauma te kan besweer, word versterk deur die voortdurende herstel van die sosiale netwerk in die beriggewing oor die wel en wee van bekendes en familie. Waar hierdie vermoë tot die uiterste beproef word, en waar dit tot niet gaan, tree skok in - 'n toestand van uiterste depressie, wat kan lei tot die dood. Hierdie toestand is aan ons bekend uit die Nazikampe van die Tweede Wêreldoorlog as die Muselmann-verskynsel, d.i. mense wat as 't ware lewende lyke is (vgl. Charny, 1992:28-54), 'n akute toestand van gedragsversteuring soortgelyk aan die sogenaamde bomskokverskynsel uit die Eerste Wêreldoorlog, en later vergelykbaar met die posttraumatiese stressindroom wat sedert die tagtigerjare gediagnoseer word by getraumatiseerde mense soos byvoorbeeld oorlogsveterane, oorlewendes van konsentrasiekampe, verkragte vroue, gemolesteerde kinders, en slagoffers van natuurrampe (vgl. Herman, 1992:7-32).

12 Dit is belangrik om op hierdie punt twee dimensies in die belang van die ander in hierdie verwerking van traumatiese ervaring te beklemtoon : eerstens die bestaan, vind of skepping van 'n herinnerng aan ' $n$ ander maar vergelykbare geval as gelykenis van oorlewing, en tweedens die moontlikheid om na 'n lewende ander vanaf die verlede en die hede uit te reik. Victor Frankl se strategie van singewing ter wille van oorlewing verreken hierdie insig op grond van sy nadenke oor persoonlike ervanngs van trauma in die Duitse uitwissingskampe (vgl. Frankl, 1972:98-103), en Bruno Bettelheim bevind dat die enigste moontlike (en daarom uiters minimale) verklaring van die oorlewing van sommige gevangenes in die uitwissingskampe die feit van 'n werkende verbintenis aan 'n medc-gevangene kan wees (Bettelheim, 1979). 'n Mens moet ook in gedagte hou dat die kwessie oor die redes vir oorlewing omstrede is. So byvoorbeeld betwis Des Pres (1976) Bettelheim en Frankl se verklarings. 'n Ander aspek wat ook verdere aandag verdien, is die moontlikheid van insiggewende en aangrypende vergelykings wat gemaak kan word tussen hierdie stel briewe van mev $\mathbf{M}$ du Toit en latere slagofferlitcratuur As gevolg van ruimtebeperkings word daar hier volstaan met blote verwysings na die volgende: Buber-Neumann (1968), Delbo (1990); Levi (1979). Die oeuvre van Paul Celan moet ook nie hier buite rekening gelaat word nie - dit kan feitlik in sy geheel getıpeer word as 'n poging om die traumatiese verlies van die ander, die "betekenisvolle jy", as gevolg van die menseslagting van die Nazi's, te besweer. Vgl. Jackson (1977). 
Van die vierde brief af word daar nje weer in sulke besonderhede op die lyding van die kinders ingegaan nie. Die trauma is een keer herleef, en daarna begin die proses van die geleidelike aanvaarding van die verlies: "ach myn liefling hun dood en gemis word elken dag swaarder ik weet zy zyn veilig maar o! die ledige plaatsen en de klederen en schoenen die niet meer gedragen wordt ik kan het niet aan zien zonder tranen" (ms 5592/16). In haar laaste brief is die rouproses bewus voltooi: Die rou-raampie is weg (wat in die vorige brief van 16 Maart nog baie breed gemaak is), daar word geen melding meer gemaak van die eie leed nie, sy is weer besorg oor die geestelike welsyn van haar man, en die brief eindig met "Blyf ik altoos uw verlangende en liefhebbende vrouw, M. du Toit" (teenoor die verswyging van die eienaam en die blote "Uw verlangende en treurende vrouw" van die vorige briewe). Hierdie naamtekening is 'n baie belangrike aanduiding van die mate waarin sy die trauma van die dood van haar kinders oorkom het. Getraumatiseerde mense ervaar wisselende mates van identiteitsverlies, omdat trauma dimensies van menswees onder druk plaas, of tydelik of permanent skend. Die ondertekening van die voorgaande briewe bloot as "uw verlangende en treurende vrouw" sê dat sy in haar leed nie haar eie en volledige self kan wees nie, en dat sy in haar leed deur haar man aangevul moet word. Wanneer sy egter deur haar treurproses is, kan sy haar volle identiteit herwin, en haarself her-definieer as die "liefhebbende" vrou van voor die tragedie (daarom die versekerende "altoos"), maar dan met die naam waarmee sy algemeen geken word, nl. M. du Toit.

\section{Die morele imperatief van trauma: nooit weer nie!}

My betoog tot dusver moes duidelik maak dat daar verskeie dimensies aan historiese trauma is, en dat elke sydigheid van historiese trauma sy waarheid vir sy tyd en plek het. Om die betekenis van hierdie trauma so goed as moontlik te peil, is dit nodig om die verskillende sydighede te onderskei en hulle so volledig moontlik te probeer verstaan. Maar die verstaan self is nie 'n blote optelsom van al die sydighede nie. Die verstaan van die betekenis van trauma het te make met insig in die wyse waarop die sydighede van die traumatiese belewenis en sy verwerking mekaar begrens en bepaal. Hierdie insig het tot dusver spesifiek in die Afrikaanse / Afrikanergeskiedskrywing ontbreek. Meer nog: die les wat uit die geskiedenis van die konsentrasiekampe voorgehou is, is ook tot nadeel van almal in hierdie land verskraal. Die morele imperatief wat tot dusver uit die geïnstitusionaliseerde herinnering van die konsentrasiekamp-geskiedenis gehoor is, is ook onnodig verskraal tot 'n opdrag dat sulke verknegting nooit weer met die Afrikaner mag gebeur nie. Dit is hoe die sydige manlike perspektief op die konsentrasiekampgeskiedenis kort na die gebeure tot 'n mank interpretasie van hierdie geskiedenis geinstitusionaliseer is. Dat die Afrikaner nooit self deel mag hê aan enigiemand anders se verknegting nie, is selde begryp, omdat die begrensing van die helde-perspektief deur dié van die empatiese feministiese waarnemer aanvanklik nie goed gehoor is nie, en later aktief teengewerk is deur 
sensuur. Die vrees vir die onheil van buite het die waaksaamheid teen die onheil van binne afgestomp. Die held- en offer-metafoor het so sterk vooropgestaan, dat die enigste onheile wat geïdentifiseer kon word, dié van verraad en dislojaliteit was. As die vraagstuk van die historiese skuld van apartheid (in die apartheidsera) geopper is, is dit gou geneutraliseer as patologiese skuldgevoelens met behulp van die (ewe patologiese) opwekking van skuldgevoelens teenoor die slagoffers van die verlede ${ }^{13}$. Dat slagoffers ontrou kon word aan die opdrag om die herhaling van lyding te voorkom, was (en is by baie mense vandag nog) ondenkbaar. In hierdie opsig deel baie wit Afrikaanssprekendes hulle sydige tot mank idealisering van slagoffers met die voorstanders van die vermaledyde Swart Bevrydingsteologie.

Die resepsie en institusionalisering van die geskiedenis van die Engelse konsentrasiekampe het ongelukkig nie gehoor gegee aan Emily Hobhouse se waarskuwings nie: dit monopoliseer lyding in 'n dubbele sin. Eerstens erken dit die lyding net van sekeres - in hierdie geval van wittes. En hierdie lyding van slegs wittes legitimeer dan die aansprake van "mede"-wittes op mag deur die vermeende verdienste van hierdie lyding - die tweede sin waarin lyding gemonopoliseer word. Dit is die gevaar verbonde aan die interpretasie van lyding as offerande ${ }^{14}$. As die logika van hierdie metafoor egter konsekwent gevolg moet word, en as die lyding van die swartes as legitiem erken word, hou dit in dat die swartes in gelyke mate aansprake kan maak op grond van die verdienste deur swart offers in hierdie geskiedenis. Daarom was dit in die

13 Vgl. byvoorbeeld G.J. Hugo (1971:81): "Verder is dit lofwaardig en 'n eis vir die sukses van parallelle ontwikkeling dat ons begaan sal wees oor ons Nie-blanke naaste. Maar ons moet waak teen 'n sieklike medemenslikheid wat die uitvoering van die [apartheids]beleid belemmer vanweë ons slap 'liefie-liefie'-arms en lam 'social gospel'-kniee en betraande 'peace corps'oe" (beklemtoning deur die outeur self). So ook A.P. Grové in Cloete (1980): "Vroeg in die jare sestig het die destydse Britse eerste minister, Harold MacMillan, die "winde van verandering' oor Afrika losgelaat, en inderhaas het Europese volkere in skuldgevoel hulle koloniale gebiede verlaat. Miljoene Swartmense het staatkundig 'vry' geword, net om in meer as een geval 'n era van bloedige diktatuur binne te gaan Maar die is om praktiese oorwegings misgekyk. In dic wêreld het slegs een sonde oorgebly, en dié sonde was apartheid. Aan hierdie wêreld met sy slagkrete, sy skynheiligheid en skuldgevoel, sy halfsagte humanisme, sy dubbele standaarde, sy omverwerping van ou waardes kon die skrywer van na 1960 nie ontsnap nie." Halfsagte humanisme was die vervloeking wat uitgespreek is oor enige vorm van kritiek op die rassisme van die apartheidsbestel. Kyk ook Steyn (1980) in hierdie verband

14 'n Baie onlangse illustrasie van die gevaar van hierdie metafoor is die hofsaak wat sommige ouers van kinders wat dood is in die Westdene-busramp van 1985 aanhangig gemaak het. Hulle het naamlik geeis dat die oorblywende geld wat in 'n rampfonds ten behoewe van hulle gestort is, aan hulle uitbetaal word. Die beweegrede tot hierdie eis was dat die algemene publiek wat tot hierdie fonds bygedra het, dit juis vir die naasbestaandes van die oorledenes bedoel het. Die versweê (maar op straat goed hoorbare) argument was dat hierdie ouers die geld "verdien" het deur hulle smart en deur die dood van hulle kinders. Die hof het teen die ouers beslis, en die oorblywende geld is oorbetaal aan die staat se fonds vir rampslagoffers 
apartheidsera vir die Afrikaner moeilik, indien nie onmoontlik nie, om sy eie konsentrasiekampgeskiedenis in 'n breër konteks te sien, behalwe om vaagweg bewus te wees van Duitse konsentrasiekampe vir Jode in die Tweede Wêreldoorlog. Dat die Duitsers dit by die Engelse sou geleer het, is van alle waarheid ontbloot. Die feit van konsentrasiekampe het met bepaalde wyses van moderne oorlogvoering en opvattings oor sosiale mag te make. Hierdie konteks bring ander volksmoorde van die moderne tyd in die kollig: 100000 dode in die Spaans-Kubaanse oorlog van 1896, 65000 dode in die Herero-opstand van 1904 tot 1907 in die destydse Duitswes-Afrika (d.i. 85\% van die destydse Hererobevolking), 1,5 miljoen Armeniërs in 1917 in die destydse Turkye, ensovoorts (vgl. Chalk \& Jonassohn, 1990). Deur die Suid-Afrikaanse konsentrasiekampepisode in 'n breër konteks in te kapsel, word myns insiens 'n kwalitatief ander kyk verkry op die aard en omvang van sosiale lyding, en word ons in staat gestel om meer daaraan te doen. Om dit nogmaals na aanleiding van Jörn Rüsen te stel: daar is dinge uit die verlede wat liefs nie verder geritualiseerde herinnering moet bly nie. Soos wat die Duitsers nie meer 'n Sedan-dag vier nie, vier Afrikaners ook nie meer Amajuba nie. Die viering as sodanig maak net nie meer sin nie. Maar daar is dinge uit die verlede wat, terwyl ons dit liefs sal wil vergeet, nie verdring kan of mag word nie. Hierdie herinnering is "pynlik en seker van openbare twis en protes", maar op die duur onvermydelik. Om die pynlike van die geskiedenis deur te werk met elke denkbare kritiese werktuig van bewuste singewing en historiese verbandhouding kom uiteindelik neer daarop om "die huidige lewensverhoudings die melodie van hulle geskiedenis voor te speel" sodat hulle beweeglik kan word vir 'n leefbare toekoms (Rüsen, 1998:233-234).

My herontginning van die konsentrasiekamp-episode van ons eie geskiedenis het nie die bedoeling om op verspeelde geleenthede te fokus sodat ons met genoeg sinisme gewapen kan wees in geval van die mislukking van die huidige poging tot sosiale restitusie in ons land nie. Die wêreld hét die afgelope eeu lesse geleer, en ons kan dit óók leer. In die kleiner konteks het ons immers geleer dat mishandelde kinders mishandelende ouers word, en ons het ook geleer dat ons iets kan doen om die bose kringloop te breek. In die groter konteks het ons geleer dat lyding wat deur die samelewing geïgnoreer, selfs verag word, 'n tydbom kan word, en ons het op 'n swaar manier geleer om daardie tydbomme te ontlont. Die konsentrasiekampe waarin Boerevroue en -kinders gesterf het, het Afrikaners ongelukkig nie verhoed om die stank van Auschwitz sonder die gaskamers en die krematoria van Auschwitz in die wêreld te versprei nie. Laat ons dan vir 'n tweede keer, met die tweede Waarheids- en Versoeningskommissie se verslag wat in 1998 gepubliseer is, leer om betyds en met insig na slagoffers te luister, sodat daar - sover as wat ons dit kan verhelp - nooit weer slagoffers van politieke magsmisbruik in Suid-Afrika sal wees nie. Soos Adorno gesê het: "Die behoefte om lyding stem te laat kry, is die voorwaarde vir alle waarheid" (Adorno, 1967:27). En waarheid is nie net 'n epistemologiese begrip 
nie. Dalk is dit in die eerste plek 'n morele begrip. Dit gee iets te kenne van die soort lewe wat gewens is vir almal om ten volle en gelukkige mense te wees.

\section{Bibliografie}

\section{Adorno, T W. 1967. Negative Dialektik. Frankfurt a.M. : Suhrkamp}

Arendt, Hannah. 1986. Elemente und Ursprünge totaler Herrschaft. München : Piper

Bergmann, Martin S \& Jucovy, Milton E. (eds.) 1982. Generations of the Holocaust. New York : Basic Books.

Bettelheim, Bruno. 1979. Surviving and other essays. New York : Knopf.

Buber-Neumann, Margarethe. 1968. Als Gefangene bei Stalin und Hitler. Stuttgart : Seewald Verlag.

Chalk, Frank \& Jonassohn, Kurt. (eds.) 1990. The history and sociology of genocide. Analyses and case studies. London: Yale University Press.

Charny, Israel W (ed.) 1992. Holding on to humanity - the message of Holocaust survivors: the Shamai Davidson Papers. New York: New York University Press.

Cloete, E. 1992. Collaborative confinement: The case of the twentieth century "Afrikaner" woman. SAVAL Conference Papers XI, April 1992, Broederstroom/Potchefstroom p 60-71.

Cloete, T T (red.) 1980. Die Afrikaanse literatuur sedert Sestig. Kaapstad : Nasou

Crowther, P 1993. Critical aesthetics and postmodernism. Oxford : Clarendon Press.

Danieli, Yael. 1981. Differing adaptational styles in families of survivors of the Nazi Holocaust: Some implications for treatment. Children Today, 10:5-10, 34-35.

Delbo, Charlotte 1990 Days and memory. Marlboro: The Marlboro Press.

Des Pres, Terence 1976. The survivor: an anatomy of life in the death camps New York Oxford University Press.

Dimsdale, Joel E. (ed.) 1980. Survivors, victims, and perpetrators. Essays on the Nazi Holocaust. New York : Hemisphere Publishing Corporation.

Epstein, H. 1979. Children of the Holocaust: Conversations with sons and daughters of survivors. New York : Putnam.

Finkelstein, Norman G. \& Birn, Ruth Bettina 1998. A nation on trial. The Goldhagen thesis and historical truth. New York : Henry Holt.

Fischer, M. 1964. Kampdagboek. Kaapstad : Tafelberg.

Frankl, Victor. 1972. The doctor and the soul. From psychotherapy to logotherapy. New York : Knopf.

Herman, Judith Lewis 1992 Trauma and recovery. New York : BasicBooks.

Hobhouse, Emily. 1902. The brunt of war and where it fell London : Methuen.

Hobhouse, Emily. 1923. Die smarte van die oorlog en wie dit gely het. Kaapstad : Nasionale Pers.

Hobhouse, Emily. 1924. War without glamour, or, women's war experiences written by themselves, 1899-1902 London : Methuen.

Hugo, GJ. 1971 Die Kleurling in Suid-Afrika kerklik-godsdienstig. In: Afrikaanse Studentebond Die Kleurling in Suid-Afrika. Referate gelewer tydens die drie-entwintigste bondskongres van die Afrikaanse Studentebond te Pretoria, Julie 1971 Johannesburg : ASB: p. 81-95.

Hobsbawm, Eric \& Ranger, Terence. (eds.) 1983. The invention of tradition. London : Cambridge University Press

Jackson, John E. 1977. Die Du-Anrede bei Paul Celan. Anmerkungen zu seinem 'Gespräch im Gebirg'. Text + Kritik, 53/54:62-68.

Krog, Antjie. 1998. Country of my skull Kaapstad : David Philip.

Leipoldt, C. Louis. 1980, Versamelde gedigte. Kaapstad : Tafelberg. 
Levi, Primo. 1979. If this is a man. The truce. London : Abacus.

Lyotard, J.-F, 1991. The inhuman: reflections on time Cambridge : Polity.

Marks, Jane. 1993. The hidden children. The secret survivors of the Holocaust. New York Fawcett Colombine

Mitscherlich, Alexander \& Margarete 1969 Die Unfahigkeit, zu trauern. Grundlagen kollektiven Verhaltens. München : Piper.

Oorlogsmuseum van die Boererepublieke Bloemfontein. Ms. 5592/12 - 5592/19.

Oorlogsmuseum van die Boererepublieke s.j. Swart konsentrasiekampe tydens die AngloBoereoorlog. Bloemfontein.

Otto, J.C. 1954. Die konsentrasiekampe. Kaapstad : Nasionale Boekhandel.

Pawelczynska, Anna 1979. Values and violence in Auschwitz. A sociological analysis. Berkeley : University of California Press.

Pries, Christine. (red) 1989. Das Erhabene. Zwischen Grenzerfahrung und Grössenwahn. Weinheim : VCH

Quindeau, Ilka. 1995. Trauma und Geschichte. Interpretationen autobiographischer Erzählungen von Uberlebenden des Holocaust. Frankfurt a.M. : Brandes \& Apsel.

Rüsen, Jörn. 1998. Die Zukunft der Vergangenheit. Universitas, 53(621):228-237.

Steyn, J.C. 1980. 'Die weeropstanding van die Bose Boer'. Aambeeld, 8(1):4-6.

Snyman, Johan. 1996. Suffering in high and low relief: war memorials and the moral imperative In: Zuidervaart, Lambert \& Luttikhuizen, Henry. (eds) Pledges of Jubilee Essays on the arts and culture, in honor of Calvin G. Seerveld. Grand Rapids Eerdmans. p. 179-209.

Snyman, Johan 1998 Interpretation and the politics of memory. Acta Juridica: 312-337.

Spies, S B 1977. Methods of barbarism? Roberts and Kitchener and civilians in the Boer Republics Jamuary 1900-May 1902. Cape Town : Human \& Rousseau.

Tec, Nechama 1986. When light pierced darkness. Christian rescue of Jews in Nazi-occupied Poland. Oxford : Oxford University Press.

Todorov, Tzvetan. 1997. Facing the extreme. Moral life in the concentration camps. New York : Henry Holt.

Van der Merwe, N.J. s.j. Die Nasionale Vrouemonument. s l. : s n.

Van Reenen, Rykie. 1984. Emily Hobhouse. Boer war letters. Cape Town : Human \& Rousseau

Warwick, P. 1983. Black people and the South African War, 1899-1902. Cambridge : Cambridge University Press

Wieseltier, Leon. 1993. After Memory. Reflections on the Holocaust Memorial Museum. The New Republic: $16-26$, May 3

Young, James E. 1993. The texture of memon: Holocaust memorials and meaning. New Haven: Yale University Press. 


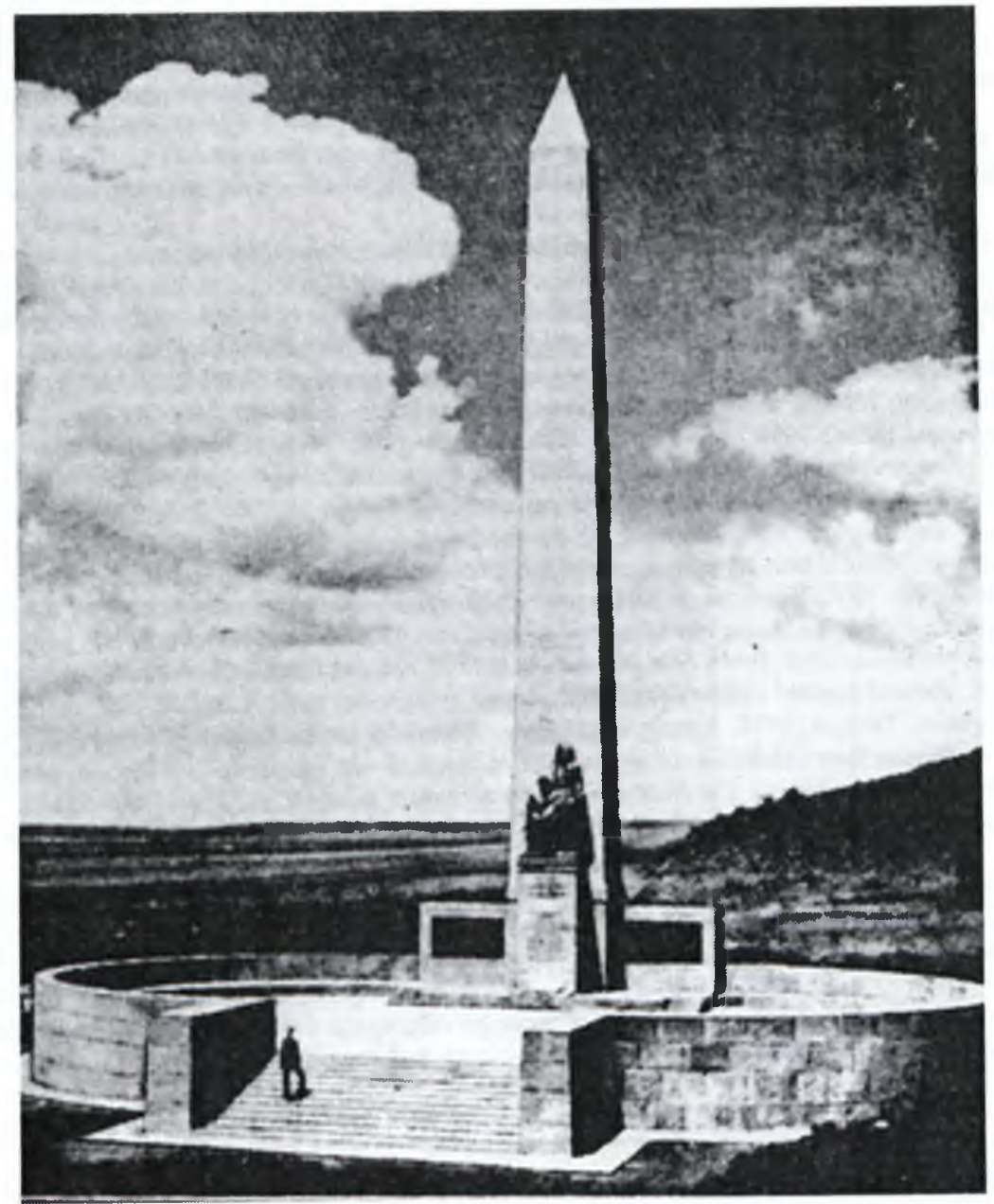

Die Vrouemonument

Fotomateriaal: Venter, E.A. 1983. Ons Geskiedenisalbum. Potchefstroom : E.A. Venter. p. 599. 